\title{
Available Evidence and Ongoing Hypothesis on Corona Virus (COVID-19) and Psychosis: Is Corona Virus and Psychosis Related? A Narrative Review
}

This article was published in the following Dove Press journal: Psychology Research and Behavior Management

\author{
Mandaras Tariku' \\ Mohammedamin Hajure (iD ${ }^{2}$ \\ 'Department of Psychiatry, College of \\ Health and Medical Sciences, Haramaya \\ University, Harar, Ethiopia; ${ }^{2}$ Department \\ of Psychiatry, College of Health and \\ Medical Sciences, Mettu University, \\ Mettu, Ethiopia
}

Background: Corona virus (COVID-19) is an outbreak of respiratory disease caused by a novel corona virus and declared to be a global health emergency and a pandemic by the World Health Organization (WHO) on March 11, 2020. Prevention strategies to control the transmission of the COVID-19 pandemic, such as closing of schools, refraining from gathering, and social distancing, have direct impacts on mental well-being. SARS-CoV-2 has a devastating psychological impact on the mental health status of the community and, particularly when associated with psychotic symptoms, it could affect the overall quality-of-life. The virus also has the potential to enter and infect the brain. As a result, psychosis symptoms could be an emerging phenomenon associated with the corona virus pandemic. The presence of psychotic symptoms may complicate the management options of patients with COVID-19.

Objective: The aim of this article review is to elaborate the relationships between COVID-19 and psychotic symptoms.

Methodology: We independently searched different electronic databases, such as Google scholar, PubMed, Medline, CINAHL, EMBASE, PsychInfo, and other relevant sources published in English globally, by using the search terms "psychosis and COVID-19", "corona virus", "brief psychotic", "schizophrenia", "organic psychosis", "infectious disease", "mental illness", "pandemics", and "psychiatry" in various permutations and combinations.

Results: The results of the included studies revealed that patients with a novel corona virus had psychotic symptoms, including hallucination in different forms of modality, delusion, disorganized speech, and grossly disorganized or catatonic behaviors. The patients with COVID-19related psychotic symptoms had responded with a short-term administration of the antipsychotic medication.

Conclusion and Recommendation: A corona virus-related psychosis has been identified in different nations, but it is difficult to conclude that a novel corona virus has been biologically related to psychosis or exacerbates psychotic symptoms. Therefore, to identify the causal relationships between COVID-19 and psychosis, the researchers should investigate the prospective study on the direct biological impacts of COVID-19 and psychosis, and the clinicians should pay attention for psychotic symptoms at the treatment center and isolation rooms in order to reduce the complication of a novel corona virus.

Keywords: COVID-19, psychosis, SARS-CoV-2, 2020

\section{Introduction}

Corona virus disease (COVID-19) is an infectious disease caused by a new virus, first detected in Wuhan, China, in December 2019. Declared to be a global health emergency and a pandemic by the World Health Organization (WHO) on March 11,
Correspondence: Mandaras Tariku Email mulatamedin@gmail.com
Psychology Research and Behavior Management 2020:13 70I-704 
2020, the disease has knocked every door in the world. Although it is characterized by mild-to-moderate respiratory illness and recovery without special treatment, older people and those with underlying medical conditions are more likely to develop serious illness and death. ${ }^{1,2}$

COVID-19 has the potential to enter and invade the brain cells and produce different neurological symptoms. The brain has been reported to express angiotensin converting enzyme 2 (ACE2) receptors that have been detected over glial cells and neurons, which makes them a potential target of COVID-19, and could be a probable cause to develop various behavioral and neurological symptoms. Prevention strategies to control the transmission of the COVID-19 pandemic, such as closing of schools, refraining from gathering, and social distancing, also have direct impacts on mental well being. ${ }^{3,4}$

Psychosis is a state in which the individual experiences a severe disconnection from reality or a loss of ego boundaries. Primarily expressed by the presence of hallucinations and delusions. Psychosis is the hallmark or defining symptoms of schizophrenia spectrum and other psychotic disorder, whereas it is associated wth features in other mental and behavioral disorders. Therefore, psychosis can be considered to be a set of symptoms in which a person's mental capacity, affective response, and capacity to recognize reality, communicate, and relate to others are impaired. ${ }^{5,6}$

Among schizophrenia spectrum and other psychotic disorders mostly, brief psychotic disorder involves the sudden onset of at least one of the positive psychotic symptoms: delusions, hallucinations, disorganized speech, or grossly abnormal psychomotor behavior. Sudden onset is defined as a change from a non-psychotic state to a clearly psychotic state within 2 weeks. A diagnosis of brief psychotic disorder requires a full remission of all symptoms and an eventual full return to the premorbid level of functioning within 1 month of the onset of the disturbance. Moreover, DSM-5 received the diagnosis of psychotic disorder due to another medical condition in which hallucination or delusion is the prominent symptoms and presence of another underlying medical condition must be involved in the pathogenesis of psychosis. The exact pathophysiology of psychotic disorders is unknown, but biological, environmental, and psychosocial factors play an important role. ${ }^{6-8}$

There are limited studies that show the causal relationship between SARS-COV or MERS-COV outbreak and psychosis. Evidence from China in 2003 during a SARS virus hypothesized that a number of patients with severe acute respiratory syndrome (SARS) developed affective psychosis during the acute phase of their illness. Additionally, among 10 patients with severe acute respiratory syndrome, three of them experienced severe psychiatric problems such as hallucinations and mania at the time of acute treatment phases. Among SARS survivors treated in the United Christian Hospital, 30 months after the SARS outbreak in China, it was shown that the cumulative incidence of DSM-IV psychiatric disorders was 58.9\%, among these the incidence of post-SARS psychotes was $4.4 \%$. High dose of steroid used (median dose of hydrocortisone equivalent $10,975 \mathrm{mg}$ vs $6780 \mathrm{mg}$ ), the direct impact of virus on the human brain, having a family history of mental illness, and poor social relationship with others were identified as probable risk factors to psychosis as compared to a control group based on a case control study in China. ${ }^{9-11}$

\section{Methodology}

We independently searched electronic databases such as Google scholar, PubMed, Medline, CINAHL, EMBASE, PsychInfo, and other relevant sources published and unpublished in English globally using the search term "psychosis and COVID-19", "corona virus", "brief psychotic", "schizophrenia", "organic psychosis", "infectious disease", "mental illness," "pandemics", and "psychiatry" in various permutations and combinations.

A total of 162 citations were retrieved using this method. On reviewing the above citations, 150 articles were excluded: because they dealt with other aspects of the COVID-19 outbreak, such as depression, anxiety, stress-related disorder, PTSD, suicide, psychological distress, and somatic symptoms disorder. The remaining 12 studies were included for this article review. Among these,seven were original articles, four were case reports, and one was a case series. As it was not possible to conduct a formal systematic review or meta-analysis given the nature of the above publications, it was instead decided to conduct a narrative review.

\section{Results}

\section{Socio-Demographic Characteristics of the Patients with COVID-19 Related Psychotic Symptoms}

Among a total of 10 patients with COVID-19 related psychotic symptoms, the mean age of the patients was $36.8 \pm 6.63$ years, and six were male. Regarding marital 
Table I Clinical Characteristics of the Patients with COVID-I9 Related Psychotic Symptoms

\begin{tabular}{|c|c|c|}
\hline Medication (mg/day) & $\begin{array}{l}\text { Previous } \\
\text { History of } \\
\text { Mental Illness } \\
\text { (Yes/No) }\end{array}$ & $\begin{array}{l}\text { Time to Full } \\
\text { Remission in } \\
\text { Days } \\
\text { (Reference) }\end{array}$ \\
\hline $\begin{array}{l}\text { Quetiapine } 500 \text { mg/day } \\
\text { Clonazepam I mg/day }\end{array}$ & No & $14^{12}$ \\
\hline$N / A$ & No & $N / A^{13}$ \\
\hline Olanzapine $10 \mathrm{mg} / \mathrm{day}$ & No & $2^{14}$ \\
\hline $\begin{array}{l}\text { Aripiprazole } 30 \text { mg/day } \\
\text { Clonazepam } 4 \text { mg/day }\end{array}$ & Yes & $17^{14}$ \\
\hline $\begin{array}{l}\text { Aripiprazole } 20 \mathrm{mg} / \text { day } \\
\text { Lorazepam } 3 \mathrm{mg} / \text { day }\end{array}$ & Yes & $13^{14}$ \\
\hline $\begin{array}{l}\text { Risperidone } 1.5 \mathrm{mg} / \text { day } \\
\text { Lorazepam } 2 \mathrm{mg} / \text { day }\end{array}$ & No & $3^{14}$ \\
\hline $\begin{array}{l}\text { Olanzapine } 25 \mathrm{mg} / \text { day } \\
\text { Paliperidone depot } \\
350 \mathrm{mg} \\
\text { Lorazepam } 2 \mathrm{mg} / \text { day }\end{array}$ & Yes & $N / A^{15}$ \\
\hline Quetiapine $25 \mathrm{mg} /$ day & No & $4^{16}$ \\
\hline $\begin{array}{l}\text { Lorazepam I mg/day } \\
\text { Aripiprazole } 2 \text { mg/day }\end{array}$ & Yes & $N / A^{16}$ \\
\hline $\begin{array}{l}\text { Quetiapine } 50 \mathrm{mg} \text { twice } \\
\text { per day }\end{array}$ & No & $N / A^{16}$ \\
\hline
\end{tabular}

Abbreviation: N/A, not reported.

status; four were married, three were single, one was divorced, and the other two were not reported.

\section{Clinical Characteristics of the Patients with COVID-I 9 Related Psychotic Symptoms}

The several cases reported from different nation on COVID-19 associated psychotic symptoms such as hallucination in various modality, delusion (for example: false beliefs that the world will end soon), disorganized speech, and grossly disorganized and catatonic behaviors. Most of the patients experienced predominant hallucinations and delusion and three of them had disorganized speech and behaviors. Among the patients with COVID-19 psychotic symptoms, most of them had no previous or past history of mental disorders. About the clinical courses of psychotic symptoms, all had acute manifestation of illness, and they received antipsychotic medication and recovered from their illness (Table 1).

\section{Discussion}

COVID-19 is continued with complexity in mode of transmission, high impacts on the economic growth, increased demand of healthcare facility, and impact on social aspects which could affect the world population at large. A patient with COVID-19 has been presented with acute psychotic reaction which could need immediate psychopharmacological medication. The psychotic symptoms can also be observed in the context of delirious patients associated with COVID-19. However, the patients with COVID-19 related psychotics were developing disorganized speech and behaviors without clouding of consciousness.

Depending on various factors that influence mental health, patients with COVID-19 may have elicited brief psychotic symptoms such as hallucinations in different modality, delusion, disorganized speech, and disorganized behaviors. Frequently hearing and working on corona virus pandemics and excessive fear about there not being enough preventive supplies and the lethal effects of COVID-19 were reported as the probable risk factors. Among elders and those who have chronic medical conditions, the presence of a positive family and previous history mental disorder, and having poor psychosocial supports were hypothesized either to provoke or exacerbate the existing mental problems during the COVID-19 pandemic. $^{13,17,18}$ SARS-CoV-2 has a adverse psychological impact on mental health status of the community, and particularly when associated with psychotic symptoms, it could affect the overall quality-of-life. ${ }^{19}$

On the other hand, people with psychotic disorder are also a high risk group for the rapid expansion of COVID19. This is due to the fact that their ability to conceptualize, think, make a decision, or realizes what is happened around the surrounding are significantly impaired to practice prevention strategies of a novel corona virus.

\section{Conclusion}

Corona virus related psychosis was identified in a different nation, but it is difficult to conclude that a novel corona virus is biologically related to psychosis or exacerbates psychotic symptoms because, during this pandemic, psychosis was observed in patients who had a previous history of mental illness and those who did not have a previous history of mental illness prior to contracting COVID-19. Therefore, the researchers, should investigate a prospective study on the direct impacts of COVID-19 on psychosis. Additionally, during the managements of patients who have 
COVID-19, the clinicians should pay attention to psychotic symptoms at the treatment center and isolation rooms in order to reduce the complications of a novel corona virus.

\section{Funding}

This research did not receive any specific grant from funding agencies in the public, commercial, or not-forprofit sectors.

\section{Disclosure}

The authors report no conflicts of interest. The authors alone are responsible for the content and writing of this article.

\section{References}

1. Rampal L, Seng LB. Coronavirus disease (COVID-19) pandemic. Med J Malaysia. 2020.

2. WHO. Novel coronavirus (2019-nCoV) situation report - 1. WHO Bull. 2020.

3. Baig AM, Khaleeq A, Ali U, Syeda H. Evidence of the COVID-19 virus targeting the CNS: tissue distribution, host-virus interaction, and proposed neurotropic mechanisms. ACS Chem Neurosci. 2020;11 (7):995-998. doi:10.1021/acschemneuro.0c00122

4. Mao L, Jin H, Wang M, et al. Neurologic manifestations of hospitalized patients with coronavirus disease 2019 in Wuhan, China. JAMA Neurol. 2020;77(6):683-690. doi:10.1001/jamaneurol.2020.1127

5. Van Os J, Linscott RJ, Myin-Germeys I, Delespaul P, Krabbendam L. A systematic review and meta-analysis of the psychosis continuum: evidence for a psychosis proneness-persistence-impairment model of psychotic disorder. Psychol Med. 2009;39(2):179-195. doi:10.1017/ S0033291708003814

6. American Psychiatry Association. DSM-5 [Internet]. American psychiatric publishing. Washington,DC: American Psychiatry Association; 2013. Available from: www.psych.org. Accessed August 8, 2020.

7. Cummings JL. Organic psychosis. Psychosomatics. 1988;29(1):16-26. doi:10.1016/S0033-3182(88)72418-4
8. Cutting J. The phenomenology of acute organic psychosis. Comparison with acute schizophrenia. Br J Psychiatry. 1987;151 (SEPT):324-332. doi:10.1192/bjp.151.3.324

9. Lee DTS, Wing YK, Leung HCM, et al. Factors associated with psychosis among patients with severe acute respiratory syndrome: a case-control study. Clin Infect Dis. 2004;39(8):1247-1249. doi: $10.1086 / 424016$

10. Cheng SK-W, Tsang JS-K, Ku K-H, Wong C-W, Ng Y-K. Psychiatric complications in patients with SARS. Br J Psychiatry. 2004;184 (4):359-360. doi:10.1192/bjp.184.4.359

11. Mak IWC, Chu CM, Pan PC, Yiu MGC, Chan VL. Long-term psychiatric morbidities among SARS survivors. Gen Hosp Psychiatry. 2009;31 (4):318-326. doi:10.1016/j.genhosppsych.2009.03.001

12. Victoria JH, Herrera D, Castillo C. Psychosis in a patient with anxiety related to COVID-19: a case report. Psychiatry Res. 2020(January). Available from: www.elsevier.com/locate/psychres.

13. Zulkifli NA, Sivapatham S, Guan NC. brief psychotic disorder in relation to coronavirus, COVID-19 outbreaks: a case report. Malaysian J Psychiatry. 2020;29(1).

14. Valdés-Florido MJ, López-Díaz Á, Palermo-Zeballos FJ, et al. Reactive psychoses in the context of the COVID-19 pandemic: clinical perspectives from a case series. Rev Psiquiatr Salud Ment. 2020;13(2):90-94. doi:10.1016/j.rpsm.2020.04.009

15. Fischer M, Coogan AN, Faltraco F, Thome J. COVID-19 paranoia in a patient suffering from schizophrenic psychosis - a case report. Psychiatry Res. 2020;288(March):113001. doi:10.1016/j.psychres.2020. 113001

16. Ferrando SJ, Klepacz L, Lynch S, et al. Case report COVID-19 psychosis: a potential new neuropsychiatric condition triggered by novel coronavirus infection and the inflammatory response? Psychosomatics. 2020;2020:1-5. doi:10.1016/j.psym.2020.05.012

17. Kozloff N, Mulsant BH, Stergiopoulos V, Voineskos AN, Outcomes EP. The COVID-19 global pandemic: implications for people with schizophrenia and related disorders. Schizophr Bull. 2020;1-6.

18. Fonseca L, Diniz E, Mendonça G, Malinowski F, Mari J, Schizophrenia GA. and COVID-19: risks and recommendations. Braz J Psychiatry. 2020;1-3.

19. Tariku M. COVID-19 and mental health in the community. East Afr J Health Biomed Sci. 2020;4(2):1-3.
Psychology Research and Behavior Management

\section{Publish your work in this journal}

Psychology Research and Behavior Management is an international, peer-reviewed, open access journal focusing on the science of psychology and its application in behavior management to develop improved outcomes in the clinical, educational, sports and business arenas. Specific topics covered in the journal include: Neuroscience, memory and decision making; Behavior modification and management; Clinical

\section{Dovepress}

applications; Business and sports performance management; Social and developmental studies; Animal studies. The manuscript management system is completely online and includes a very quick and fair peer-review system, which is all easy to use. Visit http://www. dovepress.com/testimonials.php to read real quotes from published authors. 